\title{
Comparison of Radiation Levels Emission between Compact Fluorescent Lamps (CFLs) and Incandescent Bulbs
}

\author{
M.I. IKE- OGBONNA ${ }^{1} \quad$ D.I. JWANBOT ${ }^{2 *} \quad$ E.E. IKE ${ }^{2}$ \\ 1.Department of Remedial Sciences, University of Jos, Jos- Nigeria \\ 2.Department of Physics, University of Jos, Jos- Nigeria \\ *E-mail of corresponding author: jwanbot2009@yahoo.com
}

\begin{abstract}
In this paper, the comparison of radiation levels emission between compact fluorescent lamps and incandescent bulbs were carried out with four (4) compact fluorescent lamps and four (4) incandescent bulbs using a Gamma scout $\left(\mathrm{GS}_{20}\right.$ model). The measurements were taken at varied distances of 20 to $100 \mathrm{~cm}$. The readings for window 1, window 2 and window 3 were obtained in $\mu \mathrm{Sv} / \mathrm{h}$. At distance of $20 \mathrm{~cm}$, the emissions for the compact fluorescent lamp ranged from $7.10 \mu \mathrm{Sv} / \mathrm{h}$ to $32.2 \mu \mathrm{Sv} / \mathrm{h}$ for window $1,6.70 \mu \mathrm{Sv} / \mathrm{h}$ to $28.3 \mu \mathrm{Sv} / \mathrm{h}$ for window 2 and $6.40 \mu \mathrm{Sv} / \mathrm{h}$ to $26.1 \mu \mathrm{Sv} / \mathrm{h}$ for window 3 and for the incandescent bulbs they ranged, from $2.50 \mu \mathrm{Sv} / \mathrm{h}$ to 3.60 $\mu \mathrm{Sv} / \mathrm{h}$ for window $1,2.50 \mu \mathrm{Sv} / \mathrm{h}$ to $4.00 \mu \mathrm{Sv} / \mathrm{h}$ for window 2 and $2.50 \mu \mathrm{Sv} / \mathrm{h}$ to $3.80 \mu \mathrm{Sv} / \mathrm{h}$ for window 3 . The results of the measurement and analysis carried out revealed that, there were possible ultraviolet radiation emission from the electric light bulbs with higher radiation emission from compact fluorescent lamp when compared with those from incandescent bulbs. However the values were still found to be within the safety limit.
\end{abstract}

Keywords: Radiation levels, florescent lamp, incandescent bulbs, gamma scout

\section{Introduction}

Lighting sources differ from each other in so many ways; for instance, the incandescent light bulbs have been known to produce light by heating a metal filament wire to a high temperature until it glows. These heats generated by the filament are used for various purposes such as incubators; brooding boxes for poultry etc. (Bellis, 2007).The incandescent bulbs have been in existence for many years. Approximately $90 \%$ of the power consumed by an incandescent light bulb is emitted as heat, rather than as visible light. They also work well on either alternating current or direct current; as a result they are widely used in household (Cunill-Sola.J and Salichs M (2007). However, they are being replaced in applications by other types of electric lights such as fluorescent lamp, high-intensity discharge lamps, ultraviolet fluorescent lamps, compact fluorescent lamps(CFL), light-emitting diodes(LED), electrodeless lamp also known as magnetic induction lamps, cold cathode fluorescent lamps (CCFL) and black light. These newer technologies improve the ratio of visible light to heat generation. They also produce light by luminescence and these mechanisms produce discrete spectral lines (Dahl, 2008).

Radiation is all around us and it is naturally present in our environment and has been since the birth of this planet. Consequently, life has evolved in an environment which has significant levels of ionizing radiation (Ike, 2010). It comes from outer space (cosmic), the ground (terrestrial), and even from within our own bodies. It is present in the air we breathe, the food we eat, the water we drink, and in the construction materials used to build our homes (Arogunjo, et al, 2005). High radiation doses tend to kill cells, while low doses tend to damage or alter the genetic code (DNA) of irradiated cells (Cember and Johnson, 2009). High doses can kill so many cells and tissues and organs are damaged immediately. This in turn may cause a rapid body response often called Acute Radiation Syndrome. The higher the radiation dose, the sooner the effects of radiation will appear, and the higher the probability of death. Because radiation affects different people in different ways, it is not possible to indicate what dose is needed to be fatal. Conversely, low doses - less than 10,000 mrem (100 mSv) spread out over long periods of time (years) do not cause an immediate problem to any body organ (ICRP, 1977). The effects of low doses of radiation, if any, would occur at the cell level, and thus changes may not be observed for many years (usually 5-20 years) after exposure (Ike, 2010).

\section{Materials and Method}

The light bulbs were produced to serve for $220-240 \mathrm{~V}$ and at a frequency of $50-60 \mathrm{~Hz}$. The energy efficiency of each light bulb was indicated by the manufacturer. The light bulbs were mostly those used in houses, offices, workshops, hotels and restaurants.The bulbs are designed and built to work in fixtures.

Eight samples of electric light bulbs were connected parallel one after the other on a lamp holder and the radiation level measurement was then taken using Gamma Scout ( $\mathrm{GS}_{20}$ model) for window 1, window 2 and window 3 , which are difference radiation detectors and both the mean and standard errors of the windows were calculated.

At a varied distance of $20 \mathrm{~cm}$ to $100 \mathrm{~cm}$, each different light bulb was placed and at 30 seconds intervals the radiation levels reading were taken for each of the windows in $\mu \mathrm{Sv} / \mathrm{h}$. The background count for each 
window was measured and recorded before readings were taken.

The radiation detector Gamma scout $\left(\mathrm{GS}_{20}\right.$ model) starts reading ones the radiation bottom is press, there is no need to configure it to start taking reading. It gives the readings just as indicated on the detector and displays it clear on the screen both as digital values and in form of a bar. it collects data around the clock because it is built to function all day long it does not have restricted time of operation and has a large scale calibration across a wide scale of 0.01 to $50.00 \mu \mathrm{Sv} / \mathrm{h}$. it can be used to collect data anywhere around the world.

Background counts: window 1: $2.30-2.50 \mu \mathrm{Sv} / \mathrm{h}$

Window 2: $1.90-2.10 \mu \mathrm{Sv} / \mathrm{h}$

Window 3: $2.00-2.30 \mu \mathrm{Sv} / \mathrm{h}$

Average background count for all the windows is $2.10-2.30 \mu \mathrm{Sv} / \mathrm{h}$

\section{Results}

\subsection{Discussion of results}

Tables 2, 3 and 4 show the readings obtained from radiation emission (possibly UV) for compact fluorescent lamps (energy savers bulbs) for windows 1, 2 and 3, while Tables 5, 6 and 7 also show the readings obtained from radiation emission (possibly UV) for incandescent bulbs for windows 1, 2 and 3.Tables 8 and 9 show the mean values readings calculated for both light source. Comparing the values on Table 2 with that of Table 5 for both compact fluorescent lamp and incandescent bulb for the same windows shows that the values of Table 2 are higher than that of Table 5.The measurement recorded at $20 \mathrm{~cm}$ distance for Table 2 has $14.6 \mu \mathrm{Sv} / \mathrm{h}$ for $85 \mathrm{~W}$ as the highest and $3.50 \mu \mathrm{Sv} / \mathrm{h}$ for $100 \mathrm{~W}$ as the highest for Table 5, but as the measurement progresses the values obtained for each light source reduces at farther distances from the light source and at some point the values on both light sources correspond. On Tables 3 and 6 for compact fluorescent lamp and incandescent bulbs for window 2 show that values taken for the different watt of incandescent bulbs are similar for all the distances, for instance for $200 \mathrm{~W}$ at $2 \mathrm{~cm}, 2.70 \mu \mathrm{Sv} / \mathrm{h}, 40 \mathrm{~cm}, 2.90 \mu \mathrm{Sv} / \mathrm{h}$, at $60 \mathrm{~cm}, 2.70 \mu \mathrm{Sv} / \mathrm{h}$, at $80 \mathrm{~cm}$ it is the same as 60 $\mathrm{cm}$ and $100 \mathrm{~cm}, 2.90 \mu \mathrm{Sv} / \mathrm{h}$. The same also implies for $40 \mathrm{~W}, 60 \mathrm{~W}$ and $100 \mathrm{~W}$, but those taken for compact fluorescent lamp do have some distinguishable radiation emission, at $20 \mathrm{~cm}$ values obtained for each lamp varies for each wattage. $9 \mathrm{~W}, 9.90 \mu \mathrm{Sv} / \mathrm{h}, 11 \mathrm{~W}, 13.0 \mu \mathrm{Sv} / \mathrm{h}, 26 \mathrm{~W}, 14.3 \mu \mathrm{Sv} / \mathrm{h}$ and $85 \mathrm{~W}, 25.3 \mu \mathrm{Sv} / \mathrm{h}$, which also is the same when Table 3 and Table 7 is compared.

Lastly, comparing Tables 8, 9, 10 and 11 for compact fluorescent lamp and incandescent bulb for both mean values and standard errors calculated from each Table of light sources at same distance, also shows higher values of radiation emission for compact fluorescent lamps than incandescent bulbs (Navy Environmental Health Center, 1992). However, it shows that by comparison compact fluorescent lamps have higher value of radiation emission (possibly UV radiation) at mostly $20 \mathrm{~cm}$ distance than incandescent bulbs.

\section{Conclusion}

In this study, outstanding difference has been established from the eight light bulbs studied. It has been observed that the compact fluorescent light lamps (CFLs) emitted higher values of radiation as the wattages increases and at close proximity to the bulb when compared with incandescent bulbs (Khazova and O'Hagan, 2008).which confirms the observation made by Khazova and O' Hagan in 2008. However this difference is more at $20 \mathrm{~cm}$ distance from the light source as seen on the Tables. The possible UV radiation emissions measured in this study are found to be within the acceptable radiation limit according to (ICRP, 2007), the world average background dose for human being is about $2.4 \mathrm{mSvyr}^{-1}$ for cosmic radiation and natural radionuclide in the environment. Hence may not pose a health hazard. However, it is recommended that CFLs should not be used at a very close distance, for example at bed side lamp, reading lamp etc to avoid any long-term health effects (Environmental and Radiation Health Sciences Canada, 2009).The information obtained from this research work will provide a guide for further research work regarding the light sources used in our homes, offices, workshops, hotels, restaurants etc.

\section{References}

1. Arogunjo, A M, Ofuga, E.E. and Afolabi, M .A. (2005). Levels of Natural Radionuclides in some Nigerian Cereals and Tubers. Journal of Pure and Applied Sciences 9(2): 393 - 395.

2. Bellis. M. (2007). The History of fluorescent lights.About.com. http: // inventors.about.com.

3. Cember, H. and Johnson, T. E. (2009). Introduction to Health Physics, $4^{\text {th }}$ Edition, Mc Graw-Hill, New York. Pp 220-237

4. Cunill-Sola.J and Salichs M (2007). Compact Fluorescent Lamps with Electronic Ballasts, IEEE Transactions on Power Delivery, 22: 4.

5. Dahl, M. V. (2008): New Lamps, Old Issues; CFLs and Ultraviolet Radiation .Journal Watch Dermatology, 23: 123 .

6. Environmental and Radiation Health Sciences, Canada, (2009). Report on Health Canada Survey of 
Ultraviolet Radiation and Electric and Magnetic Fields from Compact Fluorescent Lamps

7. Ike, E.E. (2010). Ionizing Radiation, Man and the Environment. Inaugural Lecture Series 43.University of Jos. Nigeria

8. ICRP, (1977). Recommendations of the International Commission on Radiological Protection ICRP Publication $263:(3)$

9. ICRP, (2007). Recommendations of the International Commission on Radiological Protection ICRP Publication 10/3: Ann37.

10. Khazova, M. and O'Hagan, J. B. (2008). Optical radiation emissions from compact fluorescent lamps. Oxford Journals Radiation Protection Dosimetry.131(4).PudMed.

11. Navy Environmental Health Center (1992). Ultraviolet Radiation Guide.

Table1: Names of energy savers lamps (compact florescent bulbs) and incandescent bulbs used.

\begin{tabular}{lll}
\hline Names & Manufacturer & Wattage(W) \\
\hline Incandescent bulb & Thungsram & 40 \\
Incandescent bulb & Thungsram & 60 \\
Incandescent bulb & Philips & 100 \\
Incandescent bulb & Pila & 200 \\
Compact fluorescent lamp & Philips Tornado & 11 \\
Compact fluorescent lamp & Zhongshan AKT lighting & 9 \\
Compact fluorescent lamp & Zhongshan AKT lighting & 26 \\
Compact fluorescent lamp & Zhongshan AKT lighting & 85 \\
\hline
\end{tabular}

Table 2: Window 1 radiation (possibly UV radiation) reading for energy saver lamps (compact fluorescent lamps)

\begin{tabular}{l|l|l|l|l}
\hline $\begin{array}{l}\text { Distance } \\
(\mathrm{cm})\end{array}$ & $\begin{array}{r}9 \mathrm{~W} \\
\mu \mathrm{Sv} / \mathrm{h}\end{array}$ & $\begin{array}{r}11 \mathrm{~W} \\
\mu \mathrm{Sv} / \mathrm{h}\end{array}$ & $\begin{array}{l}26 \mathrm{~W} \\
\mu \mathrm{Sv} / \mathrm{h}\end{array}$ & $\begin{array}{l}85 \mathrm{~W} \\
\mu \mathrm{Sv} / \mathrm{h}\end{array}$ \\
\hline 20 & 10.5 & 6.30 & 11.1 & 14.6 \\
40 & 5.40 & 5.40 & 6.10 & 14.3 \\
60 & 3.10 & 3.80 & 4.80 & 6.20 \\
80 & 3.20 & 3.10 & 3.40 & 5.90 \\
100 & 3.60 & 3.20 & 3.20 & 3.90
\end{tabular}

Table 3: Window 2 radiation (possibly UV radiation) reading for energy saver lamps (compact fluorescent lamps)

\begin{tabular}{l|l|l|l|l}
\hline $\begin{array}{l}\text { Distance } \\
(\mathrm{cm})\end{array}$ & $\begin{array}{r}9 \mathrm{~W} \\
\mu \mathrm{Sv} / \mathrm{h}\end{array}$ & $\begin{array}{r}11 \mathrm{~W} \\
\mu \mathrm{Sv} / \mathrm{h}\end{array}$ & $\begin{array}{l}26 \mathrm{~W} \\
\mu \mathrm{Sv} / \mathrm{h}\end{array}$ & $\begin{array}{l}85 \mathrm{~W} \\
\mu \mathrm{Sv} / \mathrm{h}\end{array}$ \\
\hline 20 & 9.90 & 13.0 & 14.3 & 25.3 \\
40 & 5.20 & 6.80 & 5.30 & 12.7 \\
60 & 2.90 & 4.20 & 4.40 & 6.70 \\
80 & 3.70 & 3.50 & 3.60 & 5.60 \\
100 & 3.00 & 3.10 & 2.60 & 3.00 \\
\hline
\end{tabular}

Table 4: Window 3 radiation (possibly UV radiation) reading for energy saver lamps (compact fluorescent lamps)

\begin{tabular}{l|l|l|l|l}
\hline $\begin{array}{l}\text { Distance } \\
(\mathrm{cm})\end{array}$ & $\begin{array}{r}9 \mathrm{~W} \\
\mu \mathrm{Sv} / \mathrm{h}\end{array}$ & $\begin{array}{c}11 \mathrm{~W} \\
\mu \mathrm{Sv} / \mathrm{h}\end{array}$ & $\begin{array}{l}26 \mathrm{~W} \\
\mu \mathrm{Sv} / \mathrm{h}\end{array}$ & $\begin{array}{l}85 \mathrm{~W} \\
\mu \mathrm{Sv} / \mathrm{h}\end{array}$ \\
\hline 20 & 11.7 & 6.70 & 7.30 & 26.1 \\
40 & 4.70 & 5.20 & 5.30 & 11.7 \\
60 & 3.20 & 3.70 & 4.60 & 6.50 \\
80 & 4.20 & 3.60 & 3.50 & 4.60 \\
100 & 3.10 & 3.60 & 2.50 & 3.50 \\
\hline
\end{tabular}


Table 5: Window 1 radiation (possibly $\mathrm{UV}$ radiation) reading for incandescent bulbs in $\mu \mathrm{Sv} / \mathrm{h}$

\begin{tabular}{l|l|l|ll}
\hline Distance $(\mathrm{cm})$ & $40 \mathrm{~W}$ & $60 \mathrm{~W}$ & $100 \mathrm{~W}$ & $200 \mathrm{~W}$ \\
\hline 20 & 3.10 & 2.90 & 3.50 & 3.00 \\
40 & 2.70 & 2.60 & 3.00 & 2.70 \\
60 & 2.60 & 3.60 & 3.20 & 3.30 \\
80 & 3.00 & 2.80 & 2.80 & 2.70 \\
100 & 2.80 & 2.50 & 3.00 & 3.30 \\
\hline
\end{tabular}

Table 6: Window 2 radiation (possibly UV radiation) reading for energy incandescent bulbs in $\mu \mathrm{Sv} / \mathrm{h}$

\begin{tabular}{l|l|l|l|l}
\hline Distance $(\mathrm{cm})$ & $40 \mathrm{~W}$ & $60 \mathrm{~W}$ & $100 \mathrm{~W}$ & $200 \mathrm{~W}$ \\
\hline 20 & 3.00 & 2.90 & 3.00 & 2.70 \\
40 & 2.80 & 3.30 & 2.80 & 2.90 \\
60 & 2.50 & 2.50 & 3.10 & 0.27 \\
80 & 0.26 & 0.40 & 0.37 & 2.70 \\
100 & 2.50 & 2.70 & 3.50 & 2.90 \\
\hline
\end{tabular}

Table 7: Window 3 radiation (possibly UV radiation) reading for incandescent bulbs in $\mu \mathrm{Sv} / \mathrm{h}$

\begin{tabular}{l|l|l|l|l}
\hline Distance $(\mathrm{cm})$ & $(40 \mathrm{~W})$ & $(60 \mathrm{~W})$ & $(100 \mathrm{~W})$ & $(200 \mathrm{~W})$ \\
\hline 20 & 3.20 & 3.00 & 3.80 & 3.10 \\
40 & 2.60 & 2.80 & 3.30 & 3.00 \\
60 & 2.50 & 3.50 & 3.50 & 3.10 \\
80 & 2.70 & 3.30 & 2.70 & 3.60 \\
100 & 3.00 & 3.60 & 2.90 & 2.70 \\
\hline
\end{tabular}

Table 8: Mean reading of the three radiation windows (possibly UV radiation) for energy saver lamps.

\begin{tabular}{l|l|l|l|l}
\hline $\begin{array}{l}\text { Distance } \\
(\mathrm{cm})\end{array}$ & $\begin{array}{r}9 \mathrm{~W} \\
\mu \mathrm{Sv} / \mathrm{h}\end{array}$ & $\begin{array}{c}11 \mathrm{~W} \\
\mu \mathrm{Sv} / \mathrm{h}\end{array}$ & $\begin{array}{l}26 \mathrm{~W} \\
\mu \mathrm{Sv} / \mathrm{h}\end{array}$ & $\begin{array}{l}85 \mathrm{~W} \\
\mu \mathrm{Sv} / \mathrm{h}\end{array}$ \\
\hline 20 & 10.7 & 8.70 & 10.9 & 22.0 \\
40 & 5.10 & 5.80 & 5.60 & 12.9 \\
60 & 3.10 & 3.90 & 4.60 & 6.50 \\
80 & 3.70 & 3.40 & 3.50 & 5.40 \\
100 & 3.20 & 3.30 & 2.80 & 3.50 \\
\hline
\end{tabular}

Table 9: Mean reading of the three radiation windows (possibly UV radiation) for incandescent bulbs in $\mu \mathrm{Sv} / \mathrm{h}$

\begin{tabular}{l|l|l|l|l}
\hline Distance $(\mathrm{cm})$ & $(40 \mathrm{~W})$ & $(60 \mathrm{~W})$ & $(100 \mathrm{~W})$ & $(200 \mathrm{~W})$ \\
\hline 20 & 3.10 & 2.90 & 3.40 & 2.90 \\
40 & 0.27 & 0.29 & 0.30 & 2.90 \\
60 & 2.50 & 3.20 & 3.30 & 3.00 \\
80 & 2.80 & 3.40 & 3.50 & 3.00 \\
100 & 2.80 & 2.90 & 3.10 & 3.00 \\
\hline
\end{tabular}

Table 10: Standard error for three radiation windows (possibly UV radiation) for energy saver lamps

\begin{tabular}{l|r|l|l|l}
\hline Distance $(\mathrm{cm})$ & $\begin{array}{r}9 \mathrm{~W} \\
\mu \mathrm{Sv} / \mathrm{h}\end{array}$ & $\begin{array}{l}11 \mathrm{~W} \\
\mu \mathrm{Sv} / \mathrm{h}\end{array}$ & $\begin{array}{l}26 \mathrm{~W} \\
\mu \mathrm{Sv} / \mathrm{h}\end{array}$ & $\begin{array}{l}85 \mathrm{~W} \\
\mu \mathrm{Sv} / \mathrm{h}\end{array}$ \\
\hline 20 & 1.288 & 5.037 & 4.950 & 7.422 \\
40 & 0.464 & 1.200 & 0.552 & 1.568 \\
60 & 0.224 & 0.367 & 0.245 & 0.292 \\
80 & 0.612 & 0.308 & 0.122 & 0.897 \\
100 & 0.361 & 0.367 & 0.458 & 0.575 \\
\hline
\end{tabular}

Table 11: Standard error for the three radiation windows (possibly UV radiation) for incandescent bulbs in $\mu \mathrm{Sv} / \mathrm{h}$

\begin{tabular}{|c|c|c|c|c|}
\hline Distance $(\mathrm{cm})$ & $40 \mathrm{~W} \quad \mu \mathrm{Sv} / \mathrm{h}$ & $60 \mathrm{~W} \mu \mathrm{Sv} / \mathrm{h}$ & $100 \mathrm{~W} \mu \mathrm{Sv} / \mathrm{h}$ & $200 \mathrm{~W} \mu \mathrm{Sv} / \mathrm{h}$ \\
\hline 20 & 0.141 & 0.100 & 0.570 & 0,292 \\
\hline 40 & 0.141 & 1.462 & 0.361 & 0.292 \\
\hline 60 & 0.707 & 0.812 & 0.291 & 0.038 \\
\hline 80 & 0.200 & 0.742 & 0.962 & 0.704 \\
\hline 100 & 0.203 & 0.100 & 0.570 & 0.361 \\
\hline
\end{tabular}


The IISTE is a pioneer in the Open-Access hosting service and academic event management. The aim of the firm is Accelerating Global Knowledge Sharing.

More information about the firm can be found on the homepage:

http://www.iiste.org

\section{CALL FOR JOURNAL PAPERS}

There are more than 30 peer-reviewed academic journals hosted under the hosting platform.

Prospective authors of journals can find the submission instruction on the following page: http://www.iiste.org/journals/ All the journals articles are available online to the readers all over the world without financial, legal, or technical barriers other than those inseparable from gaining access to the internet itself. Paper version of the journals is also available upon request of readers and authors.

\section{MORE RESOURCES}

Book publication information: http://www.iiste.org/book/

Academic conference: http://www.iiste.org/conference/upcoming-conferences-call-for-paper/

\section{IISTE Knowledge Sharing Partners}

EBSCO, Index Copernicus, Ulrich's Periodicals Directory, JournalTOCS, PKP Open Archives Harvester, Bielefeld Academic Search Engine, Elektronische Zeitschriftenbibliothek EZB, Open J-Gate, OCLC WorldCat, Universe Digtial Library, NewJour, Google Scholar

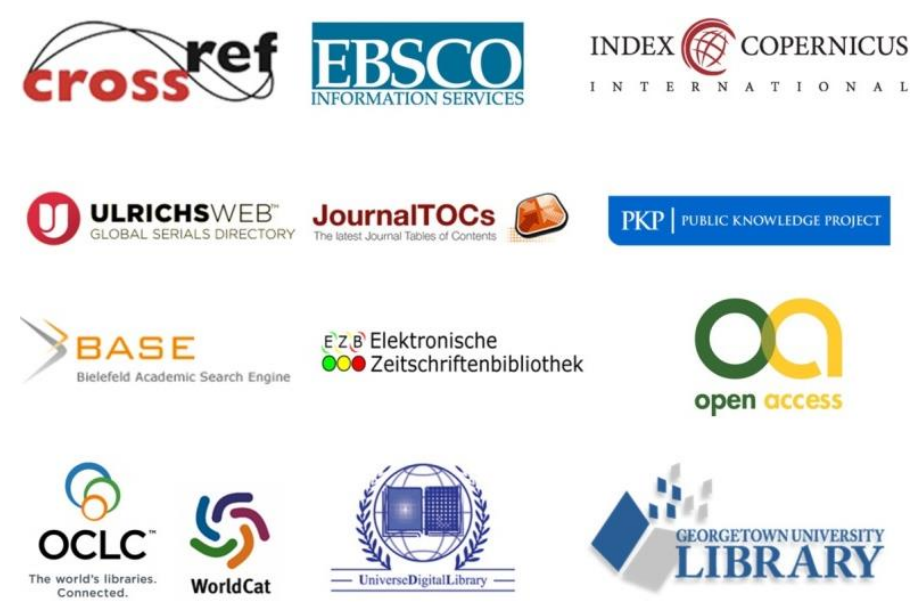

